DEMCHENKOANASTASIA,

Mariupol State University (Mariupol, Ukraine)

e-mail: anastasiademchenko92@gmail.com,ORCID 0000-0002-7730-8295

\title{
THE INDUSTRIAL INJURIES IN THE DAILY LIFE OF WORKERS OF THE METALLURGICAL INDUSTRY OF UKRAINE in the late XIX - early XX centuries
}

\begin{abstract}
The paper deals with the problem of occupational injuries in the daily life of the workers of the metallurgical industry of Ukraine in the late XIX and early XX centuries. During this period, the tendency to increase the level of occupational injuries among Ukrainian metallurgists dominated. The analysis of accidents statistics at the mining enterprises showed 3 spikes of occupational injuries: 1897-1899, 1900 and 1904. This can be explained, first, by the opening of new enterprises, which led to an increase in the number of employees, and secondly, the adoption of new legislative acts, which regulated the complete registration of all accidents at industrial enterprises. The analysis of the periodicals in the early of the XX century, reports of physicians and official statistical sources helped to comprehensively analyze the main causes and types of occupational injuries. The nature of the injuries was varied. Most of them occurred due to falling or striking heavy objects. Burns and injuries due to faulty equipment were one of the most common causes of injury in the workplace. For example, in 1901, every 38-th employee suffered from a fall or strike with a heavy subject, every 114-th of the burns, and every 127-th was injured due to defective equipment at the metallurgical plant. Complex production processes at the new metallurgical enterprises, exhausting working conditions, inexperience, inattention of newly-arrived workers and neglect of their safety rules were the main causes of accidents at metallurgical plants of Ukraine in the late XIX and early XX centuries. The issue of medical care for Ukrainian metallurgists is inextricably linked with the theme of work. In order to regulate medical assistance, the government in 1866 adopted a resolution obliging business owner to take measures for timely medical care. The factories opened hospitals. This has had a positive impact on providing first aid to the victims and their further treatment.
\end{abstract}

Keywords: everyday life; occupational injuries; accidents; metallurgists of Ukraine.

\section{Introduction}

The life of workers in the metallurgical industry of Ukraine in period of the late XIX - early XX centuries a significant place was the question of the production of daily life: the length of the working day, the conditions at work, the system of remuneration, etc. A scarce page of industrial history remains the issue of occupational injuries among metallurgists of Ukraine. The development of technology, the introduction of new technologies for the manufacture of metal has led to a complication of the production process. The level of education of workers and knowledge of safety rules did not always meet the necessary requirements. As a result, there have been accidents. Since the end of the XIX century Statistical Bureau of the Congress of Miners' Industries of the South of Russia started the statistics of accidents in the mining industry. Fixation of occupational injuries and the publication of statistical data have influenced the development and implementation of safety rules for manufacturing and health insurance for all metallurgists.

The issue of occupational injuries among metallurgists of Ukraine in the late XIX and early XX centuries in the historiographical edition is illuminated fragmentarily. The question of the conditions of life and work of workers of the Russian Empire was considered by such scientists: E. Kru- ze (1980), F. Los (1967), O. Parasunko (1963) et al. The evidence of occupational injuries among metallurgists in Ukraine is extremely fragmented. Question about the level of occupational injuries among metallurgists of Ukraine has not yet received a comprehensive coverage in historical works. Although the cases of modern occupational injuries are widely covered in the media, the scientific debate on this subject is rather poor. This can be explained by the fact that Ukrainian historic science at the present stage makes the first steps to highlight historical events by using new methods and approaches of scientific knowledge. For a long time, the tendency to rethinking the elements of macrohistory was dominant, while the microhistorical level, in particular the peculiarities of the everyday life of Ukrainian metallurgists, remained outside the scientific interests of researchers.

Separate facts from the history of occupational injuries among workers in the metallurgical industry can be found in the works of modern Ukrainian researchers, in particular: T. Vodotyka (2018) and V. Sugak (2014). Taking into account the insufficient degree of studying the problem, the aim of the paper is to cover industrial injuries of daily life of workers of the metallurgical industry of Ukraine in the late $\mathrm{XIX}$ and early $\mathrm{XX}$ centuries and determining its impact on their daily lives. 


\section{Methods}

Scientific analysis of this problem became possible due to the use of the following methods: general scientific (analysis and synthesis, generalization, induction, deduction) and specially historical (chronological, historicalcomparative, historical-system).

General scientific methods of historical knowledge were used to highlight the main causes and types of occupational injuries. The chronological method gave the opportunity to investigate the events in time sequence. Historical and comparative method has helped to reveal the main bursts of the level of occupational injuries. Due to the historical and systematic method, the problems of occupational injuries in the daily life of the workers of the metallurgical industry of Ukraine in the late XIX - early $\mathrm{XX}$ centuries has been investigated.

\section{Results}

The growth of industrial production, the development of the metallurgical industry of Ukraine in the late XIX century have affected the increase in demand for a permanent contingent of the working people. The problem of providing metallurgical enterprises was very relevant, as evidenced by the reports of the Congress of Mining Industry South of Russia (Otchet upolnomochennykh XXIII syezda gornopromyshlennikov, 1899).

In general, workers from metallurgical enterprises were people or peasants who worked seasonally. The hard work was mostly landless and landless peasants (Los et al., 1967).

The worsening of the peasants' economic situation and the rapid development of the metallurgical industry have contributed to an increase in the number of mining workers. But the lack of necessary skills for work at the plant and safety knowledge were a threat to the lives and health of the new metallurgists. Industrial accidents occurred due to the following reasons: the imperfection of production equipment, the lack of special education, employee negligence, non-compliance with legislation on the length of the working day by employers, fatigue and, consequently, reduced attention.

In 1893 the Statute of industry was adopted. It regulated the relationship between the worker and the employer. Article 156 of this Statute has established restrictions on the length of the working day. For employees in daylight hours, working time should not exceed 11.5 hours a day.
And on weekends and holidays - 10 hours. For workers employed on work partly at night (when working with one change from 21:00 to 5:00; when working with two or more changes from 22:00 to 4:00), the duration of the working day should not exceed - 10 hours (Balabanov, 1909).

The working day lasted 12 hours when the plant was operated in two shifts (Friedgut, 1994: 79). At the Dnipro plant, the working time for all categories was considered as12-hour shift. In the account book of the worker of the blast-furnace shop it was noted that on the day of rechange, the employees work without leaving the factory with two-shift work 18 hours (Los et al., 1967).

At the Iron and steel mill M. Nudelman in 1878, the working day lasted 10 hours, while at the Bellino Feneriha plant it was 10.5 hours, of which half an hour had breakfast, and one hour for lunch (Sugak, 2014). In April 1898, workers at the Kadiiv Metallurgical Plant were struck. Among the reasons for the strike, the Inspector of Slavyanoserbsky district indicated excessive working hours. "From east to sunset, with breaks for breakfast 0.5 hours and lunch 1 hour". That is, the duration of the working day was almost 13 hours (Parasunko, 1963).

The workers sometimes neglected the lunch break. This was noted by the sanitary doctor N. Kontorovich, inspecting the Petrovsky plant. The reasons for this phenomenon are clear - the working hour during a lunch break cost more (Otchet o deyatelnosti sanitarnogo vracha..., 1912).

So, metallurgists worked a lot, often neglecting their own vacation. Such an exhausting work led to the overthrow of workers. Consequently, concentration was lost, and as a result of fatigue, the risk of an occupational injury increased.

The percentage of injuries in metallurgical enterprises was higher than in mines. The authors of the work, "The History of the Donbass Workers", noted among the reasons that many works that could be mechanized were carried out by the metallurgists themselves, for example blast furnace filling (Los et al., 1967).

The research by Professor T. Frigut confirms this view. In his view, the number of accidents in the metallurgical industry was lower than in the miner's, due to the smaller number of workers. The mortality rate was lower, and the level of injury was higher (Friedgut, 1994).

Accident statistics, demonstrates the dynamics of changes in the number of victims in the production from 1893 to 1908 shown in Table 1.

Table 1. Number of accidents on mining enterprises of Ukraine $(1893-1908)$ *

\begin{tabular}{|c|c|c|c|}
\hline \multirow{2}{*}{ Year } & \multirow{2}{*}{$\begin{array}{c}\text { Total number of } \\
\text { workers }\end{array}$} & Death & Mutilation \\
\cline { 3 - 4 } & 15053 & 8 & 29 \\
\hline 1893 & 17536 & 14 & 59 \\
\hline 1894 & 16706 & 16 & 101 \\
\hline 1895 & 15906 & 26 & 273 \\
\hline 1896 & 32901 & 33 & 431 \\
\hline 1897 & 45494 & 69 & 547 \\
\hline 1898 & 49108 & 70 & 5376 \\
\hline 1899 & 53694 & 72 & 4825 \\
\hline 1900 & 52341 & 61 & 4972 \\
\hline 1901 & 44294 & 39 & 5620 \\
\hline 1902 & 37959 & 39 & 16443 \\
\hline 1903 & 40213 & 45 & 15054 \\
\hline 1904 & 42998 & 42 & 16177 \\
\hline 1905 & 43158 & 36 & 12947 \\
\hline 1906 & 47442 & 46 & 15364 \\
\hline 1907 & 46715 & 48 & \\
\hline 1908 & & & \\
\hline
\end{tabular}

* made by the author based on statistics of accidents in the mining and mining industry from 1901 - 1908. 
The above data shows the dominance of the tendency to increase the number of deaths and injuries among Ukrainian metallurgists. Analyzing the data of the table and compiled on the basis Figure 1 (Statistika neschastnykh sluchayev..., 1909), we can see three significant surges of occupational injuries: in 1897-1899, 1900 and 1904.

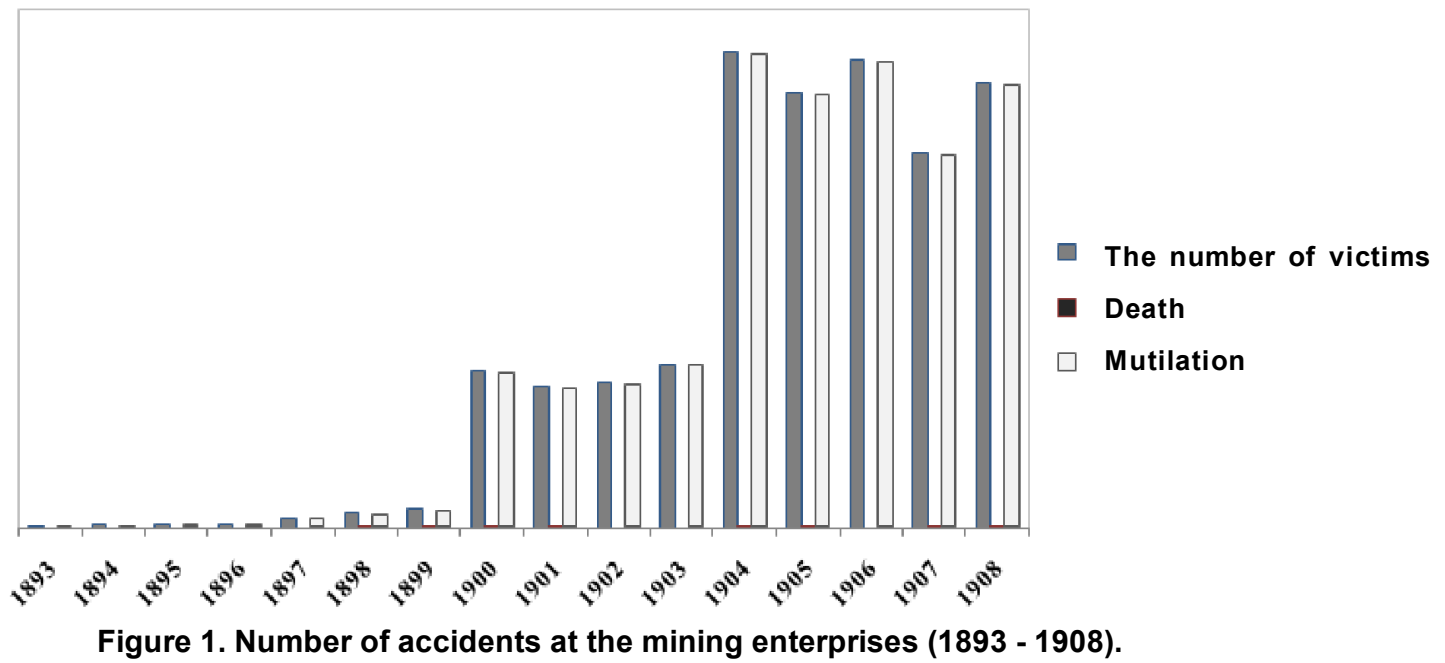

The first surge can be explained by the discovery of new enterprises. In 1897 the Kerch Plant of the Bryansk Society, the Kremenchuk private factory of masters of the Krakts, the Nikopol-Mariupol factory of the Nikopol-Mariupol Mining and Metallurgical Society and the Petrovsky Russian-Belgian Metallurgical Society were opened. In 1898 - 1899, the Kadyiv Plant of the South Russian Dnieper Metallurgical Society, the Russian Providens of the Belgian Joint Stock Company, the Olkhov Iron and Steel Melting Plant of the Olkhov Metallurgical Society, Kramatorsk and Makeevka Metallurgical Works started their work. The appearance of new jobs and an increase in the total number of metallurgists at the end of the XIX century, mainly due to former peasants who did not have professional knowledge, led to an increase in the number of traumatized miners in the mining enterprises.

Subsequent bursts of accidents were observed in 1900 and 1904. In 1900, a new document with the same was name dopted in place of the old "Orders of the Factory Inspection". Formally, the reason for its adoption were the new structural changes, which turned the real institute of district inspectors from 1882 to 1894. The document has undergone even more serious changes, in particular, it resolved the issue of fixing accidents at work.

On June 2, 1903, a law on the remuneration of workers who received industrial injuries was put into effect. Since then, according to E. Kruze, more or less complete registration by factory inspectors of cases of deaths and injuries in industry, including metallurgical plants (Kruze, 1980).

So, to explain the spikes of occupational injuries can be, firstly, the opening of new enterprises, and as a consequence of the increase in the number of workers. Secondly, the introduction of new legislative acts regulating the issues of recording accidents and providing material assistance to the victims.

From statistics on accidents with workers in the mining and mining industry for the years 1901-1902 you can learn about the nature of injuries among metallurgists of Ukraine in the early $X X$ century. The largest number of victims was observed due to falls and strikes with heavy objects (1901 - 1325 injured and 28 deaths, 1902 - 1406 injured and 9 deaths) (Statistika neschastnykh sluchayev ..., 1903).

From burns in 1901, 459 people were injured, including 4 deaths, in 1902 there were 494 injured, one of them death. From the damage to equipment in 1901, 403 people were injured and 9 died, 1902 were injured, 189 were injured and 6 died. For other reasons, in 1901, 1155 people were injured and 13 were killed, in 1902 1,661 were injured and 15 were deaths (Statistika neschastnykh sluchayev ..., 1903).

In 1901 the number of workers was 52,341 people, then every 38 -th worker was injured by the fall and strikes by heavy objects. Because of burns every 114th, and because of working with faulty equipment, every 127 th metallurgist. In 1902, the number of workers was 44294 people. Every 31-st worker suffered from falls and heavy objects. Because of burns every 89 , and because of work with the equipment, every 227 metallurgists. That is, analyzing the data on the total number of victims, the difference between 1901 and 1902 does not seem to be too significant. But, based on the fact that due to the economic crisis, early $X X$ century the total number of metallurgists has decreased, it can be seen that due to the fall and impact of heavy objects and burns in 1902, the victims were significantly more than in 1901 (at the rate of 1 accident in the total number of workers).

In 1904 the Society of Physicians of Industrial Enterprises of the Katerynoslav Province was created. In 1908, 1286 workers were inspected. The largest number of workers was made up of representatives of the metallurgical industry, namely 374 people. In particular, 157 people from the Alexander's South Russian plant, 106 from the Dnipro plant, 19 - from the steel mill (B. Ezau), 17 - from Verhnedniprovsky metallurgical plant, 17 - from Petrovsky plant, 14 - from Donetsk-Yurievsky plant, 9 - from Kramatorsk plant, 8 from Yuzovsky plant, 5 - from the Hdantsev Iron and Steel Works, 5 - from the plant "Russian Providence", 5 - from the steelworks of the General Society in Makeyevka, 4 - from the Druzhkovsky factory of the Donetsk Society, 3 - from the Kadiivsky metallurgical plant, 2 - from the factory of the Nikopol-Mariupol Society, 2 - from the iron and steel plant Leppa and Valman, 1 - from the casting plant of Moznaya in Alexandrovska (Otchet o deyatelnosti obshchestva vrachey..., 1909). The largest number of workers is represented by two metallurgical giants, which were located in Ekaterinoslav and not far from the provincial center - in Kamiansky.

The issue of medical assistance to victims was regulated at the state level. In 1866 a law was issued on the provision of medical care to industrial workers. 
According to it, at each industrial enterprise there should be an open hospital.

In 1874, the Society of Physicians in Ekaterinoslav was opened. The purpose of his activity was to unite medical workers, in order to solve complex issues. At the company of doctors there was an advisory bureau for the inspection of workers. The main objective was to certify industrial and other worker injuries. The level of occupational injuries indicates, for example, a description of the history of illnesses of workers who have been examined and treated. For example, in 1908 the 35-year-old metallurgist of the Bryansk plant was contacted by the Bureau. The history of his injuries at work is impressive. On July 5, 1899, he was crushed between two taps, resulting in damage to the chest. On February 14, 1905, during the casting of steel, he received burns of his right tibia and his right hand. On August 22, 1905 he received burns of the left eye with pig iron sparks. On July 5, 1906, a broken iron scrap hit a head and a left leg (Otchet o deyatelnosti obshchestva vrachey..., 1909).

In order to find out about injuries, Bureau employees demanded complete evidence of injuries sustained by a physician who worked at an enterprise (Otchet o deyatelnosti obshchestva vrachey..., 1909). Injured at the factories were sent for treatment to the factory hospitals. It is evidenced by archival documents. Thus, on May 22, 1907, at around $8 \mathrm{pm}$ while working at the factory of the Novorossiysk Society in Yuzovka, seven workers received burns of varying degrees of gravity from the explosion that occurred on blast furnace number 5 . Three of them were sent for treatment to the hospital. The other four received light burns and after the bandage immediately began to perform their duties (Central State Historical Archives of Ukraine in Kyiv. Fond 313. Opys 2. Sprava 1431).

Analyzing documents form 313 and form 2161, which are stored in the Central State Historical Archives in Kyiv can trace a picture of occupational injuries in 1910-1911 at individual enterprises. Thus, at the Kadyevsky plant in 1910 there were 172 accidents, in 1911 - 185. (Central State Historical Archives of Ukraine in Kyiv. Fond 2161. Opys 2. Sprava 21). Studying temporary disability benefits of less than 13 weeks for 1910-1911 at Kramatorsk and Druzhkivsky metallurgical plants can notice that 1639 people were injured in Kramatorsk in 1910, and in 1911 2002 a worker was injured (Central State Historical Archives of Ukraine in Kyiv. Fond 2161. Opys 2. Sprava 21). In Druzhkivka, in 1910, the victims of industrial injuries were 829 metallurgists, and in 1911 - 1027 people (Central State Historical Archives of Ukraine in Kyiv. Fond 2161. Opys 2. Sprava 21). The most injured were in the rolling shops. This is due to the difficult conditions of work and the complexity of the technological process.

Cases of occupational injuries in those days were actively covered in periodicals. On the pages of newspapers you can see the main causes of injury. For example, due to defective equipment in November 1915, an employee of the foundry shop at the Russian Providence plant was injured and died. During the work on him fell iron pomp weighing 200 pounds (approximately $3276 \mathrm{~kg}$ ) (Mariupolskaya zhizn, 18.11.1915).

In the yard of the expeditionary department of the Donetsk-Yurievsky factory, during the ferry transportation of iron beams, from the crankshaft of the lifting crane jumps jolted, when they hit the head of the worker of Turovsky. As a result of injury, he fell into the rails. From under the locomotive was pulled dead (Russkaya pravda, 01.07.1914).

Failure to comply with safety regulations at work has been a common cause of accidents. On May 17, 1914, a 36-year-old engineer at the Petrovsky Plant was shot down by a trolley with a brick. In severe condition, he was taken to a factory hospital. (Russkaya pravda, 25.05.1914). On June 1,1914, the engineer at the Bryansk Plant conducted maneuvers with the train. When he began to detach in the course of the warehouse with a slag form, he accidentally fell between the buffers and pushed him to death (Russkaya pravda, 04.06.1914).

In April 1915 at the plant "Russian Providens" the clutch of the cars of the blast-furnace department A. Koshalev fell to the rails, the wheels of the trolley bucket cut off his arm and leg. The workers were taken to the factory hospital for treatment. But he died the next morning (Mariupolskaya zhizn, 29.04.1915).

Accidents also occurred due to the carelessness of the workers. During the repair of a tin furnace at the Dneprovsky plant in the Kamensky, the employee Romashov, finished work and went to sleep in it. Another worker flooded the furnace without knowing that Romashov was sleeping there. The employee was pulled out of the furnace in 10 minutes dead (Russkaya pravda, 29.11.1912).

On May 24, 1914, the worker of the Mariupol Plant "Russian Providans" was swimming in the factory basin and floated to the tunnel of the blast furnace department. He was dragged by a stream of water inside the tunnel, from where he was taken dead (Russkaya pravda, 30.05.1914).

There were accidents at the metallurgical plants, several people were victims immediately. In January 1911, in the marten shop of the Yurievsky plant during the casting of a ladle with molten pig-iron, bolts were torn off. The ladle slipped over and the mass of iron was poured from it, which poured 8 workers. They all received severe burns, for two injuries, they were incompatible with life. They all received severe burns, for two injuries were incompatible with life (Russkaya pravda, 29.01.1911).

\section{Discussion}

The paper shows the causes and level of occupational injuries among workers of the metallurgical industry of Ukraine in the late XIX - early XX centuries at the background of daily life. The production processes on newly created metallurgical enterprises, working conditions of workers and their social composition are described. The peak points of accidents and occupational injuries at metallurgical enterprises have been determined and grounded. In particular: 1897-1899, 1900 and 1904 years.

Based on reports in the press of that time and reports from medical companies, the nature of occupational injuries, the level of medical care provided to the victims and measures of the Russian government that regulated this assistance and brought under it the legislative framework were determined.

Thus, a new research of topic of occupational injuries is a look at the issues from the standpoint of the daily life of workers of metallurgical industry of Ukraine during the specified period. Consideration of the issue at the local level, analysis of individual accidents in the future helps to construct a coherent picture of the daily life of Ukrainian metallurgists in the late XIX and early XX centuries.

\section{Conclusion}

Research of the topic of occupational traumatism of the workers of the metallurgical industry of Ukraine in the late XIX century - at the beginning XX century in the context of the history of daily life has a rather urgent relevance in 
novadays. This is due to several reasons: firstly, the lack of a comprehensive research by this issue, and secondly, the view from the point of view of the history of daily life allows us to reconstruct the sphere of daily life of metallurgists through the prism of general historical and special historical methods of cognition, and third, the research of past practices allows attracting the attention of the society to cases of modern occupational injuries at industrial enterprises of Ukraine.

The novelty of the research is splashes of industrial injuries have been analyzed at metallurgical enterprises of Ukraine at the first time. The causes of accidents at the factories, based on materials from periodicals of that time, were clarified. The further development of the research of the peculiarities of the daily life of the workers of the metallurgical industry of Ukraine has become further developed.

\section{REFERENCES}

Balabanov, M. (1909). Fabrichnyye zakony. Sbornik zakonov, rasporyazheniy i raz"yasneniy po voprosam russkogo fabrichnogo zakonodatelstva. St.Petersburg. (In Russian).

Central State Historical Archives of Ukraine in Kyiv. Fond 2161. Opys 2. Sprava 21.

Central State Historical Archives of Ukraine in Kyiv. Fond 2161. Opys 2. Sprava 20.

Central State Historical Archives of Ukraine in Kyiv. Fond 313. Opys 2. Sprava 1431.

Friedgut, T. (1994). luzovka and Revolution, Vol. I: Life and Work in Russia's Donbass, 1869 - 1924. Princeton (In English).

Kruse, E. (1980). Usloviya truda i byta rabochego klassa $v$ Rossii v 1900-1914 godakh. Leningrad. (In Russian).

Los, F., et al. (1967). Istoriya robitnychoho klasu Ukrayinskoyi $R S R$. Kyiv. (In Ukrainian).

Mariupolskaya zhizn. April 29, 1915. P.3 (In Russian).

Mariupolskaya zhizn. November 18, 1915. P.3 (In Russian).

Otchet o deyatelnosti obshchestva vrachey promyshlennykh predpriyatiy Yekaterinoslavskoy gubernii i uchrezhdennogo pri obshchestve konsultatsionnogo byuro dlya osvidetelstvovaniya rabochikh, postradavshikh ot neschastnykh sluchayev za 1908 god. (1909). Yekaterinoslav. (In Russian).

Otchet o deyatelnosti sanitarnogo vracha Yuzovskogo rayona Bakhmutskogo uyezda za $1911 \mathrm{~g}$. Otchety uyezdnykh sanitarnykh vrachey Yekaterinoslavskago Gubernskago Zemstva za 1911 god. (1912). Yekaterinoslav. (In Russian).

Otchet upolnomochennykh XXIII syezda gornopromyshlennikov Yuga Rossii [Report of the Commissioners of the Congress of Miners of the South of Russia]. (1899). Kharkov. (In Russian).

Parasunko, O. (1963). Polozheniye i borba rabochego klassa Ukrainy (60-90 gody XIX v.) Kyiv. (In Russian).

Russkaya pravda. January 29, 1911. P.3 (In Russian).

Russkaya pravda. July 1, 1914. P.3 (In Russian).

Russkaya pravda. June 4, 1914. P.4 (In Russian).

Russkaya pravda. May 25, 1914. P.5 (In Russian).

Russkaya pravda. May 30, 1914. P.3 (In Russian)

Russkaya pravda. November 29, 1912. P.3 (In Russian).

Statistika neschastnykh sluchayev $v$ gornoy i gornozavodskoy promyshlennosti yuzhnoy Rossii za 1901 - 1902 god. (1903). Kharkov. (In Russian).

Statistika neschastnykh sluchayev $v$ gornoy i gornozavodskoy promyshlennosti yuzhnoy Rossii za 1903 god i za 1-ye polugodiye 1904 goda. (1905). Kharkov. (In Russian).

Statistika neschastnykh sluchayev $v$ gornoy i gornozavodskoy promyshlennosti yuzhnoy Rossii za 1906, 1905 i 1904 gody. (1908). Kharkov. (In Russian).

Statistika neschastnykh sluchayev $v$ gornoy i gornozavodskoy promyshlennosti yuzhnoy Rossii za 1907, 1906, 1905 i 1904 gody. (1909). Kharkov. (In Russian).

Statistika neschastnykh sluchayev $v$ gornoy i gornozavodskoy promyshlennosti yuzhnoy Rossii za 1908-1904 gody. (1910). Kharkov. (In Russian).

Sugak, V. (2014). Vyrobnychyy travmatyzm promyslovykh robitnykiv Pivdennoyi Ukrayiny druhoyi polovyny XIX - pochatku XX st. Naukovi zapysky: Seriya "Istoriya", Issue 1(2). p. 31-34 (In Ukrainian).

Vodotyka, T. (2018). Prostir mozhlyvostey: Ukrayina $v$ dobu zaliza ta pary. Kyiv. (In Ukrainian).

\section{LIST OF REFERENCE LINKS}

Балабанов М. Фабричные законы. Сборник законов, распоряжений и разъяснений по вопросам русского фабричного законодательства. СПб., 1909.

Водотика Т. Простір можливостей: Україна в добу заліза та пари. Київ, 2018.

Крузе Э. Условия труда и быта рабочего класса в России в 1900-1914 годах. Ленинград, 1980.

Лось Ф. та ін. Історія робітничого класу Української РСР. Київ, 1967.

Мариупольская жизнь. 18 ноября 1915. С.3

Мариупольская жизнь. 29 апреля 1915. С.3

Отчет о деятельности общества врачей промышленных предприятий Екатеринославской губернии и учрежденного при обществе консультационного бюро для освидетельствования рабочих, пострадавших от несчастных случаев за 1908 год. 1909. Екатеринослав.

Отчет о деятельности санитарного врача Юзовского района Бахмутского уезда за 1911 г. Отчеты уездных санитарных врачей Екатеринославскаго Губернскаго Земства за 1911 год. Екатеринослав, 1912.

Отчет уполномоченных XXIII съезда горнопромышленников Юга России. Харьков, 1899

Парасунько О. Положение и борьба рабочего класса Украины (60-90 годы XIX в.) Киев, 1963.

Русская правда. 1 июля 1914. С.3

Русская правда. 25 мая 1914. С.5

Русская правда. 29 ноября 1912. С.3

Русская правда. 29 января 1911. С.3

Русская правда. 30 мая 1914. С.3

Русская правда. 4 июня 1914. С.4

Статистика несчастных случаев в горной и горнозаводской промышленности южной России за 1901 - 1902 года. Харьков, 1903.

Статистика несчастных случаев в горной и горнозаводской промышленности южной России за 1903 год и за 1-е полугодие 1904 года. Харьков, 1905.

Статистика несчастных случаев с рабочими горной и горнозаводской промышленности южной России за 1906, 1905 и 1904 гг. Харьков, 1908.

Статистика несчастных случаев с рабочими горной и горнозаводской промышленности южной России за 1907 , 1906, 1905 и 1904 гг. Харьков, 1909.

Статистика несчастных случаев с рабочими горной и горнозаводской промышленности южной России за 19081904 гг. Харьков, 1910.

Сугак В. Виробничий травматизм промислових робітників Південної України другої половини XIX - початку XX ст. Наукові записки: Серія "Історія". 2014. Вип. 1(2). С. 31-34.

Центральний державний історичний архів у м. Києві (ЦДІАК України), ф. 2161,оп. 2, спр. 20.

ЦДІАК України, ф. 313, оп. 2, спр. 1431

ЦДІАК України, ф. 2161, оп. 2, спр. 21

Friedgut T. luzovka and Revolution, Vol. I: Life and Work in Russia's Donbass, 1869 - 1924. Princeton, 1994. 
Демченко Анастасія,

Маріупольський державний університет (м. Маріуполь, Украӥна)

e-mail: anastasiademchenko92@gmail.com, ORCID 0000-0002-7730-8295

\section{ВИРОБНИЧИЙ ТРАВМАТИЗМ У ПОВСЯКДЕННОМУ ЖИТТІ РОБІТНИКІВ МЕТАЛУРГІЙНОЇПРОМИСЛОВОСТІ УКРАЇНИ в останній третині ХІХ - на початкУ XX cm.}

У статті розглядається проблема виробничого травматизму в повсякденному житті робітників металургійної промисловості України в останній третині XIX - на початку XX ст. У зазначений період домінувала тенденція до збільшення рівня виробничого травматизму серед українських металургів. Аналіз статистики нещасних випадків на гірничозаводських підприємствах продемонстрував три сплески виробничого травматизму: 18971899, 1900 і 1904 рр. Це можна пояснити, по-перше, відкриттям нових підприємств, що призвело до збільшення кількість працівників, а по-друге, прийняттям нових законодавчих актів, що регламентували повну реєстрацію всіх нещасних випадків на промислових підприємствах. Аналіз періодичних видань початку XX ст., звітів лікарів та офіційних статистичних джерел допомогли всебічно проаналізувати основні причини та види виробничих травм. Характер отриманих травм був різноманітним. Більшість 3 них відбулися через падіння або удари важкими предметами. Опіки та травми від несправного обладнання були одними 3 найпоширеніших причин травм на виробництві. Наприклад, у 1901 р. кожен 38-й працівник постраждав від падіння або удару важким предметом, кожен 114-й від опіків, а кожний 127-й - отримав травму через несправне обладнання на металургійному заводі. Складні виробничі процеси на новостворених металургійних підприємствах, виснажливі умови праці, недосвідченість, неуважність новоявлених працівників та нехтування ними правилами безпеки були основними причинами нещасних випадків на металургійних заводах України наприкінці XIX - на початку XX ст. Питання медичного обслуговування українських металургів нерозривно пов'язане 3 темою роботи. 3 метою регулювання медичної допомоги уряд у 1866 р. прийняв постанову, яка зобов'язали власників підприємств вживати заходів для своєчасної медичної допомоги. На заводах були відкриті лікарні. Це позитивно вплинуло на надання першої допомоги постраждалим та їх подальшого лікування.

Ключові слова: повсякдення; виробничий травматизм; нещасні випадки; металурги України.

(C) Demchenko Anastasia

Надійшла до редакції: 22.03.2019

Прийнята до друку: 19.04.2019 